Milan Vukomanović

\title{
DO JEDNOSTAVNOSTI TREBA NARASTI ${ }^{1}$
}

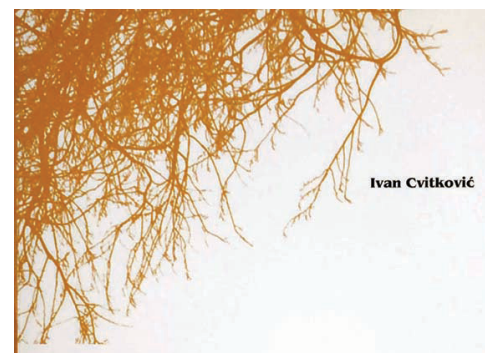

SOCIOLOŠKI POGLEDI NA NACIJU I RELIGIJU II

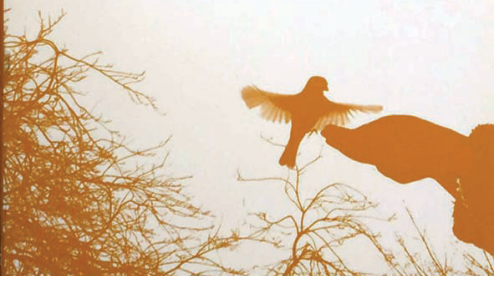

Sociološki pogledi na naciju i religiju (drugi tom) Ivana Cvitkovića je izuzetno dragoceno delo, i to ne samo zbog toga što je to 24 . knjiga po redu ovoga autora, što je numerički simbol potpunosti i savršenstva u nekim religijama. Ona ima osobit značaj jer ju je pisao autor koji se, među postjugoslovenskim sociolozima, najviše i najdetaljnije bavio problemima odnosa nacije i religije, etniciteta, nacionalizma, religije i politike. Zbog toga ovu monografiju odlikuje, pre svega, velika stručnost, kompetentnost, pouzdanost kao rezultat znanja i iskustva naučnika u zrelom dobu.

Ovo je i jedna angažovana knjiga: vrlo kritički, polemički intonirana, jer se bavi savremenim životom, kontroverzama jednog postjugoslovenskog društva i države (Bosna i Hercegovina), koje su nam bliske i u drugim državnim zajednicama. Na pitanja kao što su politika identiteta, instrumentalizacija religije, odnos morala i politike, struktura vlasti, antagonistička tolerancija, getoizacija Bosne, međunarodni protektorat, ne može se ravnodušno odgovarati, a pogotovu to ne može profesor Ivan Cvitković. Kada ga, na primer, pozovu u njegov Mostar da govori na temu Međureligijski dijalog u Evropi, on javno, na skupu, odmah pita sve prisutne: "A kakav je dijalog u Mostaru?” I onda, dok su drugi učesnici još zbunjeni, sâm odgovara: "Volio bih da sam u zabludi, ali on još nije prebrodio porođajne muke." To je upravo onaj tip angažovanosti na koji se ovde misli.

Značajno je, svakako, što je akademik Cvitković u volumenu od oko 400 stranica obuhvatio tekstove (rasprave, oglede objavljene u različitim zbornicima, priloge na konferencijama, okruglim stolovima) koji su uglavnom

${ }^{1}$ Prikaz knjige Sociološki pogledi na naciju i religiju II. Religija\&tolerancija, Novi Sad, br. 17/2012, str. 157-159. 
izlazili u periodu od 2005. do 2011. godine. Tu su se zatim našli prikazi knjiga i intervjui, zabeleške o velikanima jugoslovenske sociologije religije Srđanu Vrcanu i Đuru Šušnjiću i mnogi drugi, žanrovski heterogeni prilozi. Svi oni su, međutim, bili ranije objavljeni po različitim, teže dostupnim publikacijama za čitaoce iz regiona, pa i iz same Bosne, tako da oni u ovoj monografiji dobijaju skupa jednu dodatnu težinu. Iako sam jedan broj ovih tekstova pročitao ili čuo u izvornom obliku (u časopisu ili na nekom skupu na kome smo Cvitković i ja zajedno učestvovali), sa zadovoljstvom i neuobičajenom lakoćom za tako obimne publikacije, pročitao sam njegovu knjigu i kao celovito delo, u četiri poglavlja: 1. Kontroverze bosanskohercegovačkog društva; 2. Sociološki pogledi na naciju; 3. Sociološki pogledi na religiju; 4. Prikazi i intervjui.

U ovom tomu, međutim, ima i tekstova koji nikad ranije nisu bili objavljeni (tačnije, nisu smeli da budu objavljeni!), kao što je, na primer, jedan intervju koji je autor dao za Katolički tjednik. To verovatno ne treba da začudi ako se uzme u obzir da već na početku tog intervjua Cvitković navodi podatke o masakru 350.000 nedužnih ljudi u Meksiku u 16. veku ili 200.000 spaljenih na lomači u Evropi u ime jedne crkve. Ali da se razumemo, to nije samo tamno poglavlje u istoriji Rimokatoličke crkve. I u pravoslavnoj Rusiji su u 17. veku takođe bujali procesi protiv veštica. Štaviše, čak 1997. je u jednom ruskom selu na granici s Ukrajinom (Terehovo) čekićem i nožem napadnuta i teško povređena mlada žena pod optužbom da je veštica. Ubijena je pritom njena majka i povređeno njeno četvoro dece. Gotovo svi u selu su verovali da je ta žena veštica, a napadači su imali podršku svojih porodica. U istoriji hrišćanstva je daleko više ljudi stradalo kao posledica tobožnje borbe protiv nevernika, jeretika, veštica i drugih manjinaca, nego što su sami ti nezaštićeni manjinci predstavljali realnu opasnost za tadašnja društva. Najviše nasilja u istoriji je bilo upravo onda kada bi "bog” bio na nečijoj strani. S druge strane, danas živimo u vremenu u kome bi mediji hteli da s nama razgovaraju, ali pod uslovom da čuju ono što oni i njihovi vlasnici žele da čuju. To je ta proizvodnja saglasnosti o kojoj je pisao Noam Čomski i o tome snimio dokumentarni film još 80-ih godina (Manufacturing Consent: The Political Economy of the Mass Media, 1988).

Ivan Cvitković je autor jednostavnog jezičkog izraza. Po tome se on, na sreću svojih čitalaca, prilično razlikuje od većine sociologa. Poput našeg doajena u ovoj nauci Đura Šušnjića, i on piše onako kao što govori - jednostavno, razumljivo, neposredno, jasno, držeći se verovatno Gogoljevog gesla: Do jednostavnosti treba narasti! Navešću jedan pasus iz njegove knjige koji to rečito ilustruje: "Nacionalnost danas, poštenom čovjeku, u ovom naciona- 
lističkom blatu, može poslužiti samo kao dokaz vlastite ništavnosti. Jer, on danas nije on, on je samo 'Hrvat', 'Srbin', 'Bošnjak'. A stvarnost je da su i Hrvat i Srbin i Bošnjak u ovom gradu prazna džepa ('U gradu ni lokum više nije rahat', kaže jedan sarajevski grafit)."

Za razliku od većine svojih bosanskih kolega, profesora, Cvitković nimalo ne nastoji da bude politički korektan kada je istina u pitanju. On često svoja izlaganja na skupovima započinje in medias res, ne štedeći pritom ni organizatore: "Zašto ovakva rasprava u Zagrebu, a ne recimo u Sarajevu? Zahvalan sam organizatorima na organizaciji skupa, ali bih više volio da se on održava u Sarajevu. Tamo, očito, nema tko organizirati ovakvu raspravu. To je, nekad, mogao uraditi Institut za proučavanje nacionalnih odnosa, ali se i njega, kao 'tekovinu socijalizma', dalo zaboravu (mada je danas u BiH potrebniji nego u vrijeme socijalizma)."

U jednom prikazu objavljenom i u ovoj knjizi, Cvitković svog kolegu S. Kukića naziva angažiranim intelektualcem i taj epitet se postavlja kao antipod tzv. etnointelektualcu, pripadniku vladajuće elite u BiH. Za samog Ivana Cvitkovića bi se mogao odabrati sličan atribut - "civilni intelektualac", angažovani mislilac koji zastupa građanske, civilne, a ne etnonacionalne vrednosti i svetinje. On se pritom, kao levičar u habitusu, jasno zalaže i za socijalnu i ekonomsku pravdu, a protiv je "nove klase" koja je danas pravi mélange političara, etnointelektualaca, tajkuna, pojedinih verskih poglavara i visokih činova, medijskih monopolista, prodavaca reklama i imidža kako u Bosni, tako i ovde, u Srbiji.

Civilni intelektualci su retko popularni u svom okruženju: to važi za $\mathrm{BiH}$ kao i za Srbiju i druge postjugoslovenske države. Jer oni su najčešće u pravu kada je jedino ispravno ne biti u pravu. Parafrazirao bih naslov jednog poglavlja ove knjige: takav "obraz valja steći”, ali tek nakon dugog angažmana koji podrazumeva političku nezavisnost, nepristrasnost, akademsko i intelektualno poštenje, nepotkupljivost, spremnost da se bude i sam samcit "na ledini" sa svojim ubeđenjima od kojih se ne odstupa.

$\mathrm{U}$ baš takve intelektualce, kojih je zaista vrlo malo u ovom našem vremenu, ubrojao bih, bez ikakve rezerve, autora ove vredne i zapažene knjige - akademika Ivana Cvitkovića. 